\title{
Susceptibility to rubella in a pregnant population after the introduction of vaccination
}

\author{
E BROADBENT, N AJINA, AND ROSALINDE HURLEY \\ From Queen Charlotte's Maternity Hospital and the Institute of Obstetrics and Gynaecology, London, UK
}

SUMMARY The results of testing for the presence of rubella antibody by haemagglutination inhibition in pregnant women are presented for a number of years, together with an analysis of results for the year 1977. Levels of immunity are correlated with age and British nationality. The influence of vaccine availability on numbers with antibody cannot be demonstrated nor can any evidence for the boosting of antibody levels by natural infection be discerned.

Rubella was not recognised as a disease of major importance until 1941, when the historic work of Sir Norman Gregg correlated infection during pregnancy with damage to the child in utero (Gregg, 1941). Fetal damage induced by rubella occurs in up to $35 \%$ of cases if infection of the mother occurs in the first trimester of pregnancy, but later infections may produce sequelae, although damage is less severe and less frequent. The pathogenesis, the incidence of specific malformations and defects, and the risks to the fetus are fully described by Hanshaw and Dudgeon (1978), who also discuss preventive measures.

In an attempt to reduce or eliminate the problem of fetal damage due to rubella, a vaccine programme was launched in the United Kingdom in 1970 and a National Congenital Rubella Surveillance Programme was initiated in the following year. Hanshaw and Dudgeon have observed that the final test of protective efficacy of a vaccine is in the population as a whole. We report here the influence of the national vaccination programme on susceptibility to rubella in the population served by Queen Charlotte's Hospital, together with observations on the results of offering vaccine in the puerperium to women adjudged to be non-immune.

\section{Material and methods}

Specimens of blood are collected routinely from all patients who book for antenatal care. This is usually at 12-16 weeks' gestation. Serum is separated and screened for antibody to rubella virus using a rubella haemagglutination inhibition technique

Received for publication 2 August 1979 similar to that recommended by the Communicable Disease Center, Atlanta (US Department of Health, Education, and Welfare, 1970) but with the following variations:

Dextrose gelatin veronal buffer with bovine albumin is the buffer used throughout.

Chick cell concentration is standardised using the packed cell volume method, and nonspecific inhibitors are removed by heparin and manganese chloride.

Rubella virus haemagglutin is supplied by Wellcome Reagents.

Patients adjudged to be non-immune (antibody titre less than $1 / 16$ ) are offered rubella vaccine (Cendevax) after delivery and, where possible, are checked for seroconversion after a six-week interval (Beazley et al., 1971).

\section{Results}

LEVELS OF IMMUNITY IN THE POPULATION A total of 3000-5000 patients were screened per annum between 1971 and 1977. Analysis of the results obtained for a number of years during this period shows no clear trend of decreasing susceptibility which can be attributed to the vaccine (Table 1).

A total of 3338 women were screened in 1977.

Table 1 Percentages of seronegative patients identified between 1971 and 1977 by the rubella haemagglutination inhibition test

\begin{tabular}{lccccc}
\hline & 1971 & 1972 & 1973 & 1976 & 1977 \\
\hline $\begin{array}{l}\text { \% Seronegative } \\
\text { (RHI less than 1/16) }\end{array}$ & 17.5 & 14.7 & 15.9 & 14.7 & 16.4 \\
\hline
\end{tabular}


When grouped by age and titre of antibody there is a trend towards decreasing immunity with age. This is most clearly shown where the presence of antibody is assessed at a serum dilution of $1 / 16$ and less clearly when assessed at a serum dilution of $1 / 64$ (Table 2). At 1/16 the largest difference in immunity between sequential age groups lies between the 15-19-yearold group and the 20-24-year-old group.

Table 2 Susceptibility to rubella in 3338 pregnant women assessed by the rubella haemagglutination inhibition test (1977)

\begin{tabular}{llll}
\hline Age & $\begin{array}{l}\text { Susceptible } \\
(<1 / 16)\end{array}$ & $\begin{array}{l}\text { Antibody present } \\
\text { (serum dilution 1/16) }\end{array}$ & $\begin{array}{l}\text { Antibody present } \\
\text { (serum dilution 1/64) }\end{array}$ \\
\hline $15-19$ & $12 \cdot 5 \%$ & $87 \cdot 5 \%$ & $54 \cdot 4 \%$ \\
$20-24$ & $15 \cdot 1 \%$ & $84 \cdot 9 \%$ & $52 \cdot 1 \%$ \\
$25-29$ & $16.2 \%$ & $83 \cdot 8 \%$ & $54 \cdot 2 \%$ \\
$30-34$ & $16.9 \%$ & $83 \cdot 1 \%$ & $51 \cdot 7 \%$ \\
$35-39$ & $17 \cdot 1 \%$ & $82.9 \%$ & $47 \cdot 1 \%$ \\
$40-40+$ & $18 \cdot 2 \%$ & $81 \cdot 8 \%$ & $49.9 \%$ \\
\hline
\end{tabular}

POPULATION UNDER STUDY

The country of origin was ascertained in patients in two age groups: $22 \%$ of the 15 -19-year-olds were born outside the United Kingdom, as were $26 \%$ of the 20-24-year-olds. Immunity in these groups is compared in Table 3.

Table 3 Prevalence of rubella antibody in pregnant women born within or outside the United Kingdom

\begin{tabular}{llccr}
\hline Age & Antibody & $\begin{array}{l}\text { Non-UK } \\
\text { born }\end{array}$ & UK born & Total \\
\cline { 5 - 6 } & & & & \\
\hline \multirow{3}{*}{$15-19$} & No $(<16)$ & $4(0.5)$ & $19(127)$ & 23 \\
& Yes $(>16)$ & $38(90 \cdot 5)$ & $130(87 \cdot 3)$ & 168 \\
& Total & $42(100)$ & $149(100)$ & 191 \\
$20-24$ & No $(<16)$ & $31(17 \cdot 3)$ & $65(12 \cdot 8)$ & 96 \\
& Yes $(>16)$ & $148(82 \cdot 7)$ & $444(87 \cdot 2)$ & 592 \\
& Total & $179(100)$ & $509(100)$ & 788 \\
\hline
\end{tabular}

Percentages are given in parentheses,

RESPONSE OF WOMEN VACCINATED IN THE PUERPERIUM

In 1977 , of 555 seronegative women, $81 \cdot 7 \%$ were vaccinated and $34.9 \%$ (194) were tested subsequently for the presence of rubella antibody (Table 4);

Table 4 Results of vaccination of 194 women in the puerperium

\begin{tabular}{llllll}
\hline & \multicolumn{1}{l}{ Titre } & & & \\
\cline { 2 - 5 } & $\begin{array}{l}<8 \\
\text { (negative) }\end{array}$ & $1 / 8$ & $1 / 16$ & $1 / 32$ & $1 / 64$ or above \\
\hline $\begin{array}{l}\% \text { of tested } \\
\text { population }\end{array}$ & $4 \cdot 1$ & $8 \cdot 2$ & $23 \cdot 2$ & $29 \cdot 4$ & $35 \cdot 1$ \\
\hline
\end{tabular}

$4.1 \%$ failed to show a detectable level of antibody (less than 1/8). The remainder showed detectable antibody at serum dilutions of between $1 / 8$ and $1 / 64 ; 87 \cdot 7 \%$ had a detectable level of antibody at a serum dilution of $1 / 16 ; 31.4 \%$ of sera had a level of antibody not exceeding a titre of $1 / 16$.

\section{Discussion}

The Congenital Rubella Surveillance Programme (Sheppard et al., 1977) reports on average 67 children per annum born with congenital rubella between 1970 and 1973, and Marshall et al. (1976) reported that 2504 therapeutic abortions per annum were performed over the same period for indications relating to maternal infection with rubella. So, in this country in a non-epidemic year, rubella in pregnancy may directly or indirectly maim or terminate the lives of more than 1000 fetuses.

In an attempt to reduce or eliminate the problem of rubella in pregnancy in the United Kingdom, a vaccine programme was instituted in 1970 . Originally offering vaccine to all girls between 11 and 14 years of age, it was later extended to include some nonpregnant women of child-bearing age who were known to be susceptible, particularly those at high risk because of their occupations, for example, doctors, nurses, and teachers.

Estimation of susceptibility to rubella among the population at Queen Charlotte's Hospital was carried out in 1971 , and at that time $17.5 \%$ of our population were susceptible. Since then we have routinely screened all our patients for antibody to rubella virus, the numbers tested lying between 3000 and 5000 per annum. Table 1 shows no significant trend of decreasing susceptibility overall that can be attributed to the vaccine programme. It seemed reasonable to expect the vaccine to have had some influence on levels of immunity to rubella so further analysis was made of the data for 1977. Grouping the population in age spans of five years demonstrated that the highest level of immunity was in the youngest group (15-19 years), and, at a serum dilution of $1 / 16$, a steady decrease of immunity with age was demonstrable. The largest decrease between sequential groups at this dilution lay between the age groups 15-19 and 20-24. The rate of immunity, as assessed by presence of antibody at a serum dilution of $1 / 16$, was higher between the latter groups than between all other sequential age groups.

The group with the highest immunity (15-19 years) would have been 8-12 years old at the time of introduction of the rubella vaccination programme, and so, if resident in the United Kingdom, all in that group should have been offered the vaccine. Thus 
vaccination may explain the difference in immunity between this group and the next oldest group, for in the latter group many would already in 1970 have been too old to have been offered the vaccine.

Table 3 shows the influence of women born outside the United Kingdom on overall levels of immunity for two age groups in 1977. Those born outside the United Kingdom and aged 20-24 years show a lower level of immunity than those born within the United Kingdom. This is not seen in the younger group. Data on length of residence in the United Kingdom were not available. Comparison of those born within the United Kingdom shows little difference in the proportion with immunity in each age group.

However, statistical analysis of the figures presented in Table 3 does not confirm observed differences as having a high order of significance. Chi squared was calculated from a fourfold table using Yates' correction, and no significant difference was discernible between the age groups as a whole, between the two populations making up each group, or by comparing like populations within different age groups.

The availability of vaccine, which should have been offered to those in the younger group, does not appear to have influenced overall the proportion of women possessing rubella haemagglutination inhibition antibody assessed at a serum dilution of $1 / 16$. Although an effect is discernible in the group aged 15-19 years (Table 2), it is not statistically significant. Table 4 shows that vaccination in the puerperium gives a similar incidence of immunity when assessed at a serum dilution of $1 / 16$ to that seen in the United Kingdom born population (Table 3). However, when assessed at $1 / 64$, a level of antibody believed to confer substantial immunity (Horstman, 1976), comparison with the general population shows a significant difference $\left(\chi^{2}\right.$ fourfold test $\left.P<0.001\right)$. Only $35.1 \%$ of vaccinees have antibody as opposed to approximately $50 \%$ of the general population (Table 2).

Our assessment of immunity is made six weeks after vaccination, and we would expect titres to fall even from these levels over a number of years. Support for this view is given by other workers (Balfour and Amren, 1977). Davis et al. (1971) have shown that $25 \%$ of low responders (1/16 or less) have lost detectable rubella haemagglutination inhibition antibody (less than 1/8) five years after vaccination.

Thus, with $100 \%$ acceptance of vaccine and the titres that resulted (Table 4), if we extrapolate from the results of Davis et al. we should expect to find $12 \%$ seronegative in five years' time. This figure is close to that observed in the youngest age group where an estimated national acceptance of rubella vaccine of at least $64 \%$ is achieved (Public Health Laboratory Service, unpublished report). That the difference is not greater could be attributed to the effect of natural infection, but overall no antibody boosting effect due to this could be discerned (Table 2).

Where vaccinated individuals remain, or lapse, to become seronegative, it is unclear how susceptible they are to clinical rubella. Further studies in the laboratory and in the community are required to elucidate whether it is possible for vaccination to remove the problem of rubella in pregnancy or merely to reduce it. We have found no evidence of increased availability of vaccine causing significant change in the immunity of the population studied.

Recently, Ross and McCartney (1979) have published evidence that the high incidence of rubella in Scotland during 1978 had a booster effect on levels of antibody but we have found no hard evidence of this occurring in this study in a non-epidemic year.

\section{References}

Balfour, H. H., Jr., and Amren, D. P. (1977). Rubella vaccine (HPV-77 $\mathrm{DE}_{5}$ strain) fails to sustain antibody titres (Letter). Lancet, 2, 1130-1131.

Beazley, J. M., Hurley, R., Middlebrook, C., and Rumpus, M. F. (1971). Rubella vaccination in the puerperium. British Journal of Preventive and Social Medicine, 25, 140-143.

Davis, W. J., Larson, H. E., Simsarian, J. P., Parkman, P. D., and Meyer, H. M., Jr. (1971). A study of rubella immunity and resistance to infection. Journal of the American Medical Association, 215, 600-608.

Gregg, N. M. (1941). Congenital cataract following german measles in the mother. "Transactions of the Ophthalmological Society of Australia, 3, 35-46.

Hanshaw, J. B., and Dudgeon, J. A. (1978). "Rubella". In: Viral Diseases of the Fetus and Newborn, pp. 17-96. W. B. Saunders Company, Philadelphia, London and Toronto.

Horstman, D. (1976). "Rubella". In: Viral Infections of Humans, edited by A. S. Evans, pp. 409-427. J. Wiley, New York.

Marshall, W. C., Peckham, C. S., Dudgeon, J. A., Sheppard, S., Smithells, R.W., and Weatherall, J. A. C. (1976). Parity of women contracting rubella in pregnancy: implications with respect to rubella vaccination. Lancet, 1, 1231-1233.

Ross, C. A. C., and McCartney, A. (1979). Progress of rubella immunity in pregnant women. British Medical Journal, 1, 1636.

Sheppard, S., Smithells, R. W., Peckham, C. S., Dudgeon, J. A., and Marshall,W. C. (1977). National Congenital Rubella Surveillance, 1971-1975. Health Trends, 9, 38-41.

United States Department of Health, Education, and Welfare, Center for Disease Control, Atlanta, Georgia 
(1970). Communicable Disease Center Standard Rubella Haemagglutination Inhibition Test.
Requests for reprints to: EJ Broadbent, Queen Charlotte's Maternity Hospital,Goldhawk Road, London W6 0XG, UK.

\section{The December 1979 Issue}

\section{THE DECEMBER 1979 ISSUE CONTAINS THE FOLLOWING PAPERS}

Ultrastructure of Legionella pneumophila F. G. RODGERS

Detection of anaerobic wound infection by analysis of pus swabs for volatile fatty acids by gas-liquid chromatography P. J. REED AND P. J. SANDERSON

Significance of urinary immunoglobulins in tests for antibody-coated bacteria E. HJELM, U. FORSUM, AND L. FRÖDIN

Serodiagnosis of Trichomonas vaginalis infection by the indirect fluorescent antibody test P. R. MASON

Use of human embryo lung fibroblasts to detect a heat labile toxin of Escherichia coli from children HELEN HOLZEL

Culture diagnosis of meningococcal carriers PER OLCÉN, JAN KJELLANDER, DAN DANIELSSON, AND BO L. LINDQUIST

Pseudo-leptospires in blood culture M. RAHMAN AND F. R. MACIS

Serological grouping of streptococci by slide agglutination ANDROULLA EFSTRATIOU AND W. R. MAXTED

Grouping of streptococci by Streptex SHEENA A. WAITKINS, J. G. RATCLIFFE, R. D. ANDERSON, AND C. ROBERTS

Pseudomembranous colitis in a leukaemia unit: a report of five fatal cases D. W. MILLIGAN AND J. $K$. KELLY

Hairy-cell leukaemia: an immunoperoxidase study of paraffin-embedded tissues J. H. C. GOOI, G. F. BURNS, AND J. C. CAWLEY

Assessment of thrombocytopenic patients for splenectomy J. D. M. RICHARDS AND D. S. THOMPSON
C-reactive protein for rapid diagnosis of infection in leukaemia P. H. MACKIE, R. A. CROCKSON, AND J. STUART

Mechanisms of smooth muscle antibody production F. KANAKOUDI-TSAKALIDIS, C. CASSIMOS, T. PAPASTAVROU-MAVROUDI, T. AKOGLU, B. H. TOH, A. YILDIZ, O. OSUNG, E. J. HOLBOROW, AND J. SOTELO

Detection of human antibodies to hepatitis B surface antigen ( $\mathrm{HBsAg}$ ) by an enzyme-immunoassay for HBsAg G. WOLTERS, L. KUIJPERS, AND A. SCHUURS

A histochemical comparison of the $\mathrm{O}$-acylated sialic acids of the epethelial mucins in ulcerative colitis, Crohn's disease, and normal controls C. F. A. CULLING, P. E. REID, AND W. L. DUNN

Nuclear diameter in parathyroid adenomas $\mathrm{H}$. M. LLOYD, J. M. JACOBI, AND R. A. COOKE

Liver damage due to perhexiline maleate G. B. FORBES, M. O. RAKE, AND D. J. E. TAYLOR

Clinical significance of an ultrafast alkaline phosphatase isoenzyme JOHN KOETT, JAMES HOWELL, AND PAUL L. WOLF

\section{Technical methods}

A rapid bile solubility test for pneumococci $R$. HOWDEN

Plastic embedding of transbronchial biopsy specimens for light microscopy c. W. EDWARDS, ANNA KRYPCZYK, AND A. BROWNHILL

Automatic Gram staining by a linear conveyor system G. V. HEIMER AND D. A. MCSWIGGAN

A method of highlighting the macroscopic patterns of congenital cystic kidneys J. T. LIE

Letter to the Editor

Book reviews

Index to Volume 32

Copies are still available and may be obtained from the PUBLISHING MANAGER, BRITISH MEDICAL ASSOCIATION, TAVISTOCK SQUARE, LONDON WC1H 9JR, price $£ 3.00$, including postage 